\title{
A model of mean reversion in stock prices and the Equity Premium Puzzle 株価の平均回帰性についてのモデルとエクイティプレミアムパズル
}

\author{
Yuuki Maruyama
}

\begin{abstract}
In this model, the stock price is determined by two variables: the fundamental value and the current risk preference of people. Suppose that the fundamental value follows Geometric Brownian motion and the function of the risk preference of people follows Ornstein-Uhlenbeck process. There are only two types of asset: money (safe asset) and stocks (risk asset). In this case, the profit rate of equity investment is mean reverting, and long-term investment is more advantageous than short-term investment. The market is arbitrage-free. Also, based on this model, I suggest a solution to the Equity Premium Puzzle.
\end{abstract}

株式の価格を、ファンダメンタルな価值と社会のリスク選好度の 2 変数として表すモデルを考える。フ アンダメンタルな価值が幾何ブラウン運動に従い、社会のリスク選好度の関数が Ornstein-Uhlenbeck 確率過程に従うとする。資産には、貨幣（安全資産）と株式（リスク資産）の二種類のみが存在するとす る。この場合、株式投資の利益率には平均回帰効果が生じることを示し、長期投資が短期投資に比べて有 利であることを証明する。市場において、無裁定条件は保たれている。また、このモデルに基づき、エク イティプレミアムパズルへの一つの解決策を提示する。

\section{1 序論}

株式投資には平均回帰効果があると言われており、平均回帰効果が存在するという実証研究も多く存 在する。しかし、証券理論においてはその効果は否定されており、長期投資の方が有利というのは間違い であるとされている。平均回帰効果を説明できる理論として広く認められているものは存在しない。今 回この論文において、新たな株式の価格決定法を提唱し、理論の帰結として平均回帰効果が説明できる ことを示す。また、同理論に基づいて、エクイティプレミアムパズルに対する 1 つの解決策を提案する。 企業の時価総額というのは、理論研究においては、将来にわたる配当の予想額のみに基づき算出される ことが多い。しかし、将来にわたる配当の予想額が全く変化しなくても、人々のリスク選好度が変化すれ ば、企業の時価総額は変化するもののはずである。なぜなら、リスク選好度が低下すれば、人々はリスク 資産よりも安全資産を好むようになり、株式というリスク資産への評価額を下げるためである。純粋に 将来にわたる配当の予想額によって算出された企業価值を企業のファンダメンタルな価值と呼ぶことに すると、企業の時価総額というのは企業のファンダメンタルな価值と人々のリスク選好度の 2 つにっ て定まる值であると言えるだろう。今回の理論においては企業の時価総額をこれら 2 つの值に分解して 考えるところがポイントである。 
まず、企業のファンダメンタルな価值についてである。今回の理論では、企業のファンダメンタルな価 值こそが幾何ブラウン運動に従うものとする。事業というのは収益を生み出すものであるが、事業のフ

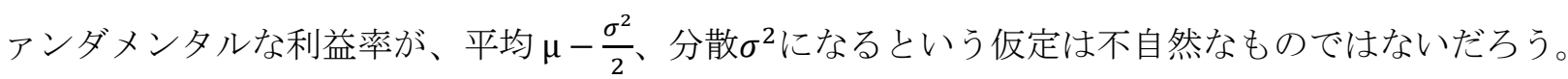

次に、人々のリスク選好度である。この值（より正確にはこの值の関数）が平均回帰過程になると仮定 する。一時的に社会の風潮としてリスク選好度が高まることはあっても、人間の本質的なリスク選好度 は時代を通して大きく変わることはないだろうという仮定に基づく。実際、Shiller の CAPE レシオを 人々のリスク選好度としてとらえて良いなら、おおむね平均回帰傾向にあるように見受けられ、平均值 から乘離する時代もあるが再度平均值に戻ってくる傾向があると推測できる。リスク選好度が平均回帰 過程にあるという仮定もあながち非現実的なものとは言えないだろう。

この 2 つを組み合わせて企業の時価総額が決まるものとする。この場合、株式投資には平均回帰効果 が生まれ、長期投資の方が有利となることを示す。

\section{2 モデル}

事業のファンダメンタルな収益率を、平均 $\mu-\frac{\sigma^{2}}{2}$ 、分散 $\sigma^{2}$ とする。

また、 $\mathrm{t}$ 期における株価を $S_{t}$ 、ブラウン運動を $B_{t}$ 、リスク資産と安全資産の相対価格を $P_{t}$ とする。 このとき

$$
S_{t}=\frac{P_{t}}{P_{0}} S_{0} \exp \left(\left(\mu-\frac{\sigma^{2}}{2}\right) t+\sigma B_{t}\right)
$$

となる。

株式投資の利益率は $\log \frac{S_{t}}{S_{0}}$ で表されるが、

$$
\log \frac{S_{t}}{S_{0}}=\log \frac{P_{t}}{P_{0}}+\left(\mu-\frac{\sigma^{2}}{2}\right) t+\sigma B t
$$

ここで、 $p_{t}=\log \frac{P_{t}}{P_{0}}$ とし、 $p_{t}$ が Ornstein-Uhlenbeck 確率過程（平均回帰過程）に従うものとする。

(Ornstein-Uhlenbeck 確率過程に従うものが、リスク選好度, $P_{t}, p_{t}$ のいずれであっても本質に影響は ないが、単純化のため $p_{t}$ とする。)

$$
\mathrm{d} p_{t}=a\left(b-p_{t}\right) d t+\theta d B_{t}
$$

とする。 $\mathrm{b} は p_{t}$ の長期的な平均值であり、 $\mathrm{a}$ は $p_{t}$ の平均回帰速度である。定義より $p_{0}=0$ となる。

平均を $\mathrm{E}$, 分散を $\mathrm{V}$ とすると

$$
\begin{gathered}
\mathrm{E}\left[p_{t}\right]=p_{0} e^{-a t}+b\left(1-e^{-a t}\right)=b\left(1-e^{-a t}\right) \\
\mathrm{V}\left[p_{t}\right]=\frac{\theta^{2}}{2 a}\left(1-e^{-2 a t}\right)
\end{gathered}
$$


ここで、 $\mathrm{t} \rightarrow \infty$ の時、

$$
\begin{gathered}
\lim _{t \rightarrow \infty} \mathrm{E}\left[p_{t}\right]=b \\
\lim _{t \rightarrow \infty} \mathrm{V}\left[p_{t}\right]=\frac{\theta^{2}}{2 a}
\end{gathered}
$$

また、 $\mathrm{t} \rightarrow 0$ の時、

$$
\begin{aligned}
& \lim _{t \rightarrow 0} \mathrm{E}\left[p_{t}\right]=a b t \\
& \lim _{t \rightarrow 0} \mathrm{~V}\left[p_{t}\right]=\theta^{2} t
\end{aligned}
$$

故に、株式の長期投資の利益率は

平均 $\mu-\frac{\sigma^{2}}{2}$ 分散 $\sigma^{2}$

株式の短期投資の利益率は

平均 $\mathrm{ab}+\mu-\frac{\sigma^{2}}{2} \quad$ 分散 $\theta^{2}+\sigma^{2}$

となる。 $\mathrm{ab}$ が十分に大きくない限りは、長期投資は短期投資よりも有利であると言える。

\section{3 考察}

投資をする際は、長期投資目的ならば株式の比率を高めるべきであるし、短期投資目的ならば株式の比 率を抑えるべきである。リスク回避度が等しい人であっても、貯蓄の目的に応じて最適なポートフォリ オは変わってくるということになる。

ちなみにこのモデルにおいて、社会のリスク選好度が低い時に株式を買い、社会のリスク選好度が高い 時に株式を売る、という取引については、ファンダメンタルな価值が幾何ブラウン運動に従いリスクが ある以上、無リスク取引にはならず、裁定取引には当たらない。

最後に、エクイティプレミアムパズルについて述べる。人々が貯蓄をする目的にも種類がある。老後の ための資金としての貯蓄であれば長期投資ということになり、株式の比率を高めるべきである。しかし、 急に資金が必要になる場合に備えての予備的貯蓄については、いつ株式を売却する必要が出るか分から ないため短期投資ということになり、株式の比率は抑えるべきである。もし人々の貯蓄動機の内、後者の 予備的貯蓄の割合が多いなら、エクイティプレミアムが非常に高くても矛盾しない。以上がエクイティ プレミアムパズルに対する解決策の一案である。

\section{参考文献}

Fama, E. F., \& French, K. R. (1988). Permanent and temporary components of stock prices. Journal of political Economy, 96(2), 246-273.

Poterba, J. M., \& Summers, L. H. (1988). Mean reversion in stock prices: Evidence and implications. Journal of financial economics, 22(1), 27-59. 